\title{
Teaching Elementary Accounting To Non-Accounting Majors
}

Cynthia B. Lloyd, Morgan State University, USA

Augustus Abbey, Morgan State University, USA

\begin{abstract}
A central recurring theme in business education is the optimal strategy for improving introductory accounting, the gateway subject of business education. For many students, especially nonaccounting majors, who are required to take introductory accounting as a requirement of the curriculum, introductory accounting has become a major obstacle for achieving their goal of obtaining undergraduate degree in business. This paper reviews a variety of common but underutilized strategies for presenting learning opportunities to non-accounting majors in their first accounting course. Effective teaching methodologies that will promote active learning to help non-accounting majors develop interest in accounting and enhance their critical thinking skills in the acquisition of accounting knowledge are explored. Included in this review are discussions about the adjustments that can be made relative to class size and individuality in the early precourse stages. Teaching strategies such as the use of remedial modules, case studies, hands-on student participation opportunities, within or separate from the classroom lecture, mini-quizzes, and mnemonics are discussed. Guidance is offered to accounting academics who wish to fulfill their responsibility to students in the most difficult, rule-dominated, math-oriented, and consequently, "high risk" course of introductory accounting.
\end{abstract}

Keywords: non-accounting majors, teaching methodologies, active learning

\section{INTRODUCTION}

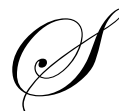

tudies that explored the factors leading to university enrollment declines of accounting majors report that such declines have been largely due to the perceptions held among non-accounting majors regarding the accounting profession (Tan and Laswad, 2005; Saudagaran, 1996). Some other studies have reported that accounting professors themselves may be influential in students' decision to major or not major in accounting (Tan and Laswad, 2005; Paolillo and Estes, 1982; Cangelosi, Condie, and Luthy, 1985). This suggests that as an extension of the professors' influence, the teaching methodologies utilized by professors for conveying the subject of accounting are important aspects in shaping students' proclivities for accounting. Non-accounting majors have been observed as the group of students most likely to be challenged or turned off by the subject of accounting (Saudagaran, 1996). With accounting as a gateway subject in the business curriculum, concerned administrators and designers of university programs of business administration must be cognizant of the important function of strategic teaching methodologies in changing non-accounting majors' perceptions about accounting.

The purpose of this paper is to propose active learning strategies that are known to (1) help non-accounting majors learn to process accounting concepts in terms of the course material, by offering them the opportunity to use practical thinking skills, (2) assist students' evaluation of evidence, (3) offer non-accounting majors the otherwise unavailable opportunities to devise applications of accounting principles, (4) enhance or develop eagerness to learn more about accounting, (5) aid in the articulation of what the students learned, and (6) provide immediate feedback regarding student comprehension or confusion (McKeachie 2006).

Elementary accounting as the first accounting course is considered to be one of the most important business courses because its course content plays a key part in the academic success of students who are non-accounting majors (Tan and Laswad, 2006). At the same time, elementary accounting, given its quantitative nature, tends to fall 
under the category of courses labeled as a high risk with high rate of failure among non-accounting majors. Thus changes in content and teaching strategies must be implemented for successful results (Cohen and Hanno, 1993). It is important that instructors of elementary accounting develop the skills and techniques that are necessary for the effective teaching of the course. If used effectively, accounting instructors may alter the negative perceptions that discourage students from majoring in accounting.

\section{ACCOUNTING AND NON-ACCOUNTING MAJORS COMPARED}

At the beginning of the first accounting course, even though certain assumptions about the non-accounting major student may be presumptuous, they are important, nonetheless. First, the motivations for taking the first course in accounting are usually different. For non-accounting majors, the motivation is typically to meet a requirement of the business school's curriculum. Secondly, the learning style and background of non-accounting majors could be very different from that of accounting majors (Tan and Laswad, 2006). For instance, research has shown that accounting students who perform well tend to have strong mathematical skills (Gist 1998), or had previous exposure to accounting by way of college preparatory high school bookkeeping or accounting courses (Eskew and Faley 1988). Factors included in deciding not to major in accounting include mathematics (Gist 1990). It is assumed that students who are not equipped with strong background in mathematics will not choose accounting as a major, and thus a majority of non-accounting majors may need remedial work in the area of mathematics.

Learning can be made more difficult when a teacher fails to recognize that they have a natural tendency to explain concepts in a way that may not match how the non-accounting major might perceive is the best way to learn. Since most accounting teachers are themselves accountants, that tendency can be problematic for a non-accounting major, who naturally, may be less motivated to learn accounting than his or her accounting-major cohorts. The teacher must determine the most effective teaching style can be used to achieve the learning goals. In Brown (2005) the issue of this mismatch was discussed in terms of the deterrence of students from learning the accounting discipline when the student does not fit the stereotypical accountant's profile. Further, within the framework of style, teachers must determine which teaching methodology, for example, lecture, discussion, case studies, experiential learning, computer/technology aided learning, best helps in achieving the learning outcomes for non-accounting majors. Adaptation could improve students' educational experiences, by the use of language and teaching materials designed to match the students' meta program preferences (Brown, 2005). Students enrolled in accounting classes with different business concentrations might learn better through different teaching/learning techniques (Rodrigues, 2004). Certain learning environments require certain teacher behaviors, such that the students' needs and the course needs may not match. For example, accounting topics require a high degree of teacher direction, which may not be compatible with a particular student's learning techniques (Rodrigues, 2004). Thus, customizing techniques found to be congruent to the learning styles of students from different concentrations involves continuously rethinking the accounting course for non-accounting majors. The instructor must consider maximum topic coverage, as well as methodology, i.e., lecture or active learning, for maintaining student interest and understanding (Cunningham, 1999).

\section{RELEVANT ACCOUNTING TOPICS FOR NON-ACCOUNTING MAJORS}

As far back as the early 1960s, researchers have wrestled with the idea of determining the essential subject matter for first-year basic accounting courses offered to students who are non-accounting majors (Zukowsky, 1961). Some views are that this decision hinges upon whether the educator believes a separate course should be established for non-accounting majors (Zukowsky, 1961). Even then, Zokowsky (1961) proposed that the prevailing opinion was, that compared to the accounting major, the non-accounting major should attain a much broader concept of accounting from the course in basic accounting. Of the thirty-four technical proficiency topics considered in the Zulowsky (1961) study of the essential topics to be taught to non-accounting majors in first-year elementary accounting courses, certified public accountants (CPAs) were in favor of including all thirty-four of the topics, while executives preferred fourteen, alumni preferred five, and surprisingly, instructors preferred the inclusion of only one topic. In the area of general understanding topics, eighty-nine topics were considered. In this area, executives thought that eighty-four topics were important, while alumni were in favor of including eighty topics and professors with CPAs favored the inclusion of seventy-nine topics. The degree of the inclusion was another matter between the instructors and the CPAs. The resulting conclusion of the study is that for non-accounting majors in the elementary 
accounting course, a general understanding of accounting is more important than interpreting accounting with technical proficiency.

\section{TEACHING STRATEGIES FOR NON-ACCOUNTING MAJORS}

Many active learning strategies for teaching accounting to non-accounting majors have been offered in accounting education research (Kaulback 1951; Perry 1959; Zukowsky 1961; Cloyd 1971; Shotwell 1999; Jones and Fields 2001). Ambiguities and uncertainties regarding accounting concepts can be clarified by using gentle probing questions. Journal writing topics can be assigned at the end of class sessions, homework style in-class exercises can be worked through, working in cooperative learning groups can be assigned to brainstorm problem solutions. Finally, role-playing exercises can be beneficial near the end of the accounting course (Cunningham 1999).

Other methods for teaching accounting include, having students read the textbook either inside or outside the classroom, read worked-out example problems (or objective questions), listen to the lecture, answer short objective questions, discuss issues with other students, conduct research, have students make oral presentations and answer questions, involve students in demonstrations (role playing, simulation games, experiments).

Interestingly, in comparative studies of accounting versus non-accounting business faculty, the accounting educator's point of view regarding the best teaching practices for effective outcomes in elementary accounting courses continues to be slightly different from that other business faculty. In almost every area except student inclass presentations, lectures were ranked higher by accounting instructors (Brown and Guilding 1993). The literature indicates that while teaching a subject with a strong practical focus, such as accounting necessitates the coverage of factual and technical aspects of the discipline, the instructor is not precluded from also offering lessons in the discipline from the abstract or relational level. Although changing the accounting teacher's orientation appears to be extremely difficult, the literature continues to point to the need to develop student-centered or conceptual change orientation to teaching and learning introductory accounting (Leveson 2004). The results of research indicate that while there is evidence that other techniques prove to be better for improved learning outcomes, accounting instructors continue to be very resistant to change.

Research supports the well-established notion that students' conceptions of the subject matter have an effect on their approaches to learning (Lucas 2001; Marton and Saljo, 1976; Biggs, 1976; Sharma, D.S. 1997; Prosser and Trigwell, 1997). That is, styles, motivations and each student's study method will depend upon the teaching and learning context (Biggs, 1976). As a result of the context, those students not majoring in accounting will apply either a deep or surface approach to learning introductory accounting (Lucas, 2001). Students are either attracted to accounting because of its logic and clarity, or they may be repelled by preconceptions of boredom or dealing with numbers (Lucas, 2001). In attempting to look into the real life world of students, and the affective ways of learning accounting, Lucas (2001) found that in the final analysis, in teaching introductory accounting, students must be engaged with alternative ways of looking at the subject matter, and the accounting instructor must engage with alternative ways of viewing the non-accounting major that might tap into their perception of the personal relevance of accounting.

\section{INCREASING ACCOUNTING LITERACY}

Accounting is seen as the language of business (Feast, Kokkinn, Medlin and Frangiosa, 1999). Although there have been various attempts to define the term "accounting literacy" its plain meaning can be summarized through a set of objectives developed for the first course in accounting. The objectives are achieved if by the use of both individual and collaborative efforts, the student understands the language used in accounting and how accounting conceptual information is used and if they can perform steps to record the data systematically and prepare reports that communicate findings from the information recorded (Feast et. al., 1999). Learning techniques are discussed in the following sections that could enhance the accounting literacy of non-accounting majors who are challenged in grasping accounting concepts. 


\section{The Accounting Mini-Module}

Students are presumed to begin any college curriculum with broad differences in ability, likewise, it can be expected that the student, unexposed to, or uninterested in accounting may have challenges in relating to the subject matter. Shotwell (1999) gave evidence that achievement can be enhanced for business students through the introduction of fundamental business concepts such as accounting if pre-semester "accounting mini-courses" are added to the business school curriculum. The study indicated that such a required first semester course for all freshmen and transferring students taught in a non-threatening environment had a positive effect on the passing rates of all business students later enrolled in the first semester accounting course. The outcomes envisioned include enhancing the development of core competencies (Saudagaran, 1996) of non-accounting majors, increase student confidence, decrease anxiety, modify the perception about accounting, increase retention of the material and thus reduce attrition rates of all business students, especially non-accounting majors.

\section{Supplemental Instruction}

Since research has found that achievement in the first course in accounting is critically important for the development of skills essential to be successful for accounting careers, as well as non-accounting careers, it should follow that non-accounting majors in elementary accounting courses, could benefit from increased reading, reasoning and study skills developed in supplemental instruction contexts. Accounting instructors can use proactive supplemental instruction on a regularly scheduled basis to assist students in mastering core accounting course concepts. This methodology could increase academic performance through fostering better reading, reasoning and study skills (Jones and Fields 2001; Congos and Schoeps 1993). Jones and Fields (2001) observed the emergence of a step pattern, in that students who attended more sessions, outperformed students attending fewer sessions. Thus, mandatory attendance, or even voluntary attendance in supplemental instruction sessions for non-accounting majors in elementary accounting is an effective way to increase students' academic performance.

\section{ACTIVE LEARNING TECHNIQUES}

Active learning techniques should be applied liberally, but as McKeachie (2006) suggests, they should supplement, not supplant traditional learning techniques such as lectures and reading, which can also be utilized for active learning opportunities. McKeachie reports that students' knowledge gain is enhanced in student directed discussions. Also, he indicates that since active learning need not be limited to the in-class environment, he recommends the utilization of technology to facilitate learning for both the in-class and out-of-class learning environment.

The teacher in any classroom is responsible, not only for teaching, but for setting the tone, providing the right learning atmosphere. First, for all accounting students, especially those either unfamiliar with accounting, not interested in accounting, or for those not choosing to major in accounting, it is important that the instructor share his or her understanding of how accounting information affects resource allocation throughout the world (Cunningham 1999). Cunningham (1999) offers that while large lectures are useful for conveying very complicated and large amounts of information, the best learning approach for longer retention for most students is actively grappling with accounting issues and problems. The facilitation of active learning can be accomplished through its constant interspersion into beginning accounting courses by including active learning techniques within lectures (Cunningham 1999).

\section{A Hands-On Conceptual Model}

The active, hands-on conceptual approach can be used to illustrate basic accounting concepts to nonaccounting majors who may be primarily challenged only in the business discipline-specific area of accounting. The major benefit in using these active learning techniques is that students' problem solving skills are enhanced in comparison to those skills that might have been attained through a lecture-only environment (Kern 2002). 


\section{Case Studies}

The advantages of the case method of bridging the gap in accounting education through active student participation have been found through several studies (Stewart and Dougherty 1993; Saudagaran 1996; Milne and McConnell 2001; Adler, Whiting and Wynn-Williams 2004; Springer and Borthick, 2004; Lucas, 2001). The studies range from discussions of how accounting educators should use case studies through a problem-based learning process (Adler et al 2004), to using case studies to emphasize the idea that the single solution strategy to accounting is not the best approach (Saudagaran, 1996). The case study approach is implemented by the use of groups who engage in a problem-solving process which starts with the student gathering the necessary information, acquiring an understanding of new concepts and developing new skills as necessary to solve problems. In addition to tapping students' learning strengths, such as significant improvement in essay exam performance, researchers have found that the case study method served to improve students' interest in certain accounting areas (Stewart and Dougherty 1993). Springer and Borthick (2004) indicate that in the case study approach engages the students, since all accounting students, including non-accounting majors can be cast in the role of experts. This in turn serves to help to clarify and reinforce learning as they communicate their findings. The use of their acquired knowledge allows nonaccounting majors to grasp the relevance of accounting in the broader business context by helping them to construct their own representations of how a business operates (Springer and Borthick, 2004).

\section{Cooperative Learning}

A teaching strategy not requiring much faculty preparation, and applicable in a wide variety of formats, is student team learning or cooperative learning. The cooperative learning strategy has been found to be an effective approach for reducing the percentage of unprepared accounting students and thus, reducing the percentage of uninterested students in principles of accounting courses. One of the results found from these changes in preparedness and interest, is an increase in enrollment in basic accounting courses (Ravenscroft, Buckless, McCombs and Zuckerman 1995), especially, presumably increasing enrollment numbers of non-accounting majors. Evidence from research in this area has found the resulting benefits of the use of this strategy to be pronounced. Further, it has been found that even in the face of complaints regarding academic free riding, those complaints can be eliminated through the instructor's use of the proper incentives in a cooperative, student-to-student learning context. The study of this approach shows that it can be a powerful tool for allowing students to control their own learning in the context of basic accounting education (Ravenscroft et al 1995). Support of the hypotheses regarding the resulting overall superior improvement in student performance when graded cooperatively should be persuasive to accounting educators that the benefits to non-accounting majors may very well seriously outweigh any risks associated with adopting this strategy.

\section{Frequent or Unannounced Quizzes}

Using quizzes as a method of study in preparation for examinations is not a new concept, in that its use dates back to 1935 (McKenzie 1972). Using a regime of frequent instructor-made quizzes in conjunction with postquiz discussions for the instructional value early in the course, was found to produce higher achievement, and higher retention, especially for students with inferior algebra and geometry abilities (Felduson 1964). Although there had been little prior research in accounting education regarding quiz efficacy, Graham (1999) experimented with the effect of giving unannounced quizzes, as contrasted to utilizing announced quizzes, in teaching challenging concepts. (Lieber, 2003; Mawhinney, Boston, Laws, Blumenfeld, and Hopkins, 1971; Murphy and Stanga, 1994). Anderson (1984) found that announced quizzes had no effect in improving later test grades. On the other hand, Graham's (1999) study showed a positive effect on test scores from the use of unannounced quizzes, and prior studies he discussed found that frequent announced quizzes enhance the distribution of studying, and therefore motivated students to decrease cramming, gets the students to read prior to the lecture, and increases their comprehension. Moreover, Graham (1999) found that when queried, the majority of students replied that despite the anxiety generated by unannounced quizzes, this strategy should be used on a wider basis. In attempting innovative techniques, requiring a form of active learning, we found similar results to those documented in prior research, in informal experimentation with a strategy that involved a pre-announced five-item or less "mini-quiz" at the end of every class session, coupled with a longer ten-item take-home, teacher-made exercise/quiz every third class session. Almost every session was structured so that the mini-quizzes are graded in the classroom to facilitate immediate 
feedback. Each quiz or exercise was followed by a discussion of the material either immediately after grading or in the following class session.

\section{Study Aids and Mnemonics}

In teaching accounting to mostly non-accounting majors, the authors developed and utilized a set of mnemonics using the first letter of each word in a series of concepts that could easily be recalled when needed. Through our own experience, we recall that while not all non-accounting majors are challenged by mathematical concepts or reading skills, they may simply be put off by the unfamiliar world of business terminology and accounting concepts, beginning with the expressions: "debits" and "credits". Indeed experimentally, it was discovered that by using mnemonics for amusement, students' could be coaxed into quickly memorizing and recalling important accounting concepts. At the Allied Academies International (2002) Conference, educators revealed that through the use of mnemonics, students had better recall, improved long-term retention, the motivation to learn is sustained, along with improving their reasoning skills and bettering their text processing, as well as increasing test scores by $77 \%$ with the mnemonic strategy (Toney-McLin 2002). In developing mnemonics for nonaccounting majors, accounting instructors must remember that the most important aspect of motivation through mnemonics is there should be an element of fun in the process. Bear in mind that peculiar, stimulating, vivid, three dimensional or humorous mnemonics that maintain a flow of association are more effective than static images (Toney-McLin 2002). This technique is worth exploring, as studies have found significant group effect from the use of mnemonics, as in teaching mathematics to students who are learning disabled (Manalo, Bunnell, Stillman 2000).

\section{CONCLUSIONS}

This study of teaching elementary accounting to non-accounting majors explored not only the importance of accounting to future business participants, but learning strategies applicable to teaching elementary accounting to non-accounting majors. This study of the unique needs of non-accounting majors in the basic accounting context extends prior analyses of this subject matter. Evidence has shown that various styles of learning and teaching techniques should be, as they have been, a major concern in teaching accounting courses. One goal of this paper is to promote active learning, by encouraging accounting instructors to in carefully utilize multiple teaching and learning strategies.

No guidance has been provided in this paper regarding the challenges associated with finding the optimum combination of learning strategies in order to achieve the best results in an accounting for non-accounting majors specific environment. Since the educational environment needed for achieving the best learning outcomes vary among universities and student demographic characteristics, no one single teaching method or one combination of teaching methods can be recommended with assurance that optimum learning goals will be achieved. With that said, research continues to bear out how essential it is to include active learning strategies in accounting education for non-accounting majors, regardless of how active learning is combined with other teaching and learning strategies.

While accounting academicians continue to ponder whether accounting education for non-accounting majors is too narrow, little or no action appears to be taken. Since there is no standardized system or one-size-fits-all program for all accounting students, we encourage curriculum designers to develop appropriate programs that include all the available options considering the strengths, weaknesses and demographics of the student body, and in

light of the environment the student faces. Accounting instructors must explore the use of active learning, energize the classroom, and use other innovative strategies to motivate non-accounting majors to excel in the accounting classroom.

\section{REFERENCES}

1. Adler, R.W., Whiting R.H., and Wynn-Williams, K. 2004. Student-led and teacher-led case presentations: empirical evidence about learning styles in an accounting course. Accounting Education 13: 213-229.

2. Anderson, J.E. 1984. Frequency of quizzes in a behavioural science course: an attempt to increase medical student study. Teaching of Psychology 11(1): 34. 
3. Biggs, J.B. 1976. Individual differences in study processes and the quality of learning outcomes. Higher Education 8: 381-94.

4. Brown, N. 2005. Meta programmes for identifying thinking preferences and their impact on accounting students' educational experience. Journal of Accounting Education 23: 232-247.

5. Brown, R.B. and C. Guilding. 1993. A survey of teaching methods employed in university business school accounting courses. Accounting Education 2: 211-218.

6. Cangelosi, J.S., Condie, F.A. and Luthy, D.H. 1985. The influence of introductory accounting courses on career choices. Delta Pi Epsilon Journal 27(1): 60-68.

7. Cloyd, H.M. 1971. Optimum course requirements for non-accounting majors. The Accounting Review 46(3): 591-594.

8. Cohen, J. and Hano, D.M. 1993. An analysis of underlying constructs affecting the choice of accounting as a major. Issues in Accounting Education 8(2): 219-238.

9. Congos, D.H. and Schoeps, N. 1993. Does supplemental instruction really work and what is it anyway? Studies in Higher Education 18(2): 165-175.

10. Cunningham, B.M. (1999). Energizing your teaching: a view from deep in the trenches. Issues in Accounting Education 14: 307-321.

11. Eskew, R.K. and R.H. Faley 1988. Some determinants of student performance in the first college-level accounting course. Accounting Review 53: 137-147.

12. Feast,V., Kokkinn,B. Medlin,J. and Frangiosa,R. 1999. Accounting for student diversity. paper presented at the of the Higher Education and Research Development Society of Australasia (HERDSA): Cornerstones. Melbourne, Australia: July 12-15.

13. Felduson, J.F. 1964. Student perception of frequent quizzes and post-mortem discussions of tests. Journal of Educational Measurement 1: 51-54.

14. Gist, W.E., H. Goedde and Ward, B.H. 1996. The influence of mathematical skills and other factors on minority student performance in principles of accounting. Issues in Accounting Education 1: 49-60.

15. Graham, R.B. 1999. Unannounced quizzes raise test scores selectively for mid-range students. Teaching of Psychology 26: 271-273.

16. Jones, J.P. and Fields, K.T. 2001. The role of supplemental instruction in the first accounting course. Issues in Accounting Education 16: 531-547.

17. Kaulback, F.S. 1951. Elementary accounting and the non-accounting major - a proposal. The Accounting Review 26: 102-104.

18. Kern, B.B. 2002. Enhancing accounting students' problem-solving skills: the use of a hands-on conceptual model in an active learning environment. Accounting Education 11: 235-256.

19. Leveson, L. 2004. Encouraging better learning through better teaching: a study of approaches to teaching accounting. Accounting Education 13: 529-548.

20. Lieber, R.J. 2003. The five-minute quiz. Journal of Accounting Education 21(3): 261-265.

21. Lucas, U. 2001. Deep and surface approaches to learning within introductory accounting: a phenomenographic study. Accounting Education 10: 161-184.

22. Manalo, E., Bunnell, J.K. and Stillman, J.A. 2000. The use of process mnemonics. Learning Disability Quarterly 23: 137-156.

23. Marton, F. and Saljo, R. 1976. On qualitative differences in learning: outcome and process. British Journal of Educational Psychology 46: 4-11.

24. Mawhinney, V.T., Boston, D.E., Laws, D.L., Blumenfeld, G.J. and Hopkins, B.L. 1971. A comparison of students studying-behavior produced by daily, weekly, and three-week testing schedules. Journal of Applied Behavior Analysis 4(1971): 257-264.

25. McKeachie, W.J. and Svinicki, M. 2006. McKeachie's teaching tips: strategies, research, and theory for college and university teachers, Boston: Houghton Mifflin.

26. McKenzie, G.R. 1972. Some effects of frequent quizzes on inferential thinking. American Educational Research Journal 9: 231-240.

27. Milne, M.J. and McConnell, P.J. 2001. Problem-based learning: a pedagogy for using case material in accounting education. Accounting Education 10: 61-82.

28. Murphy, D.P. and Stanga, K.G. 1994. The effects of frequent testing in an income tax course: an experiment. Journal of Accounting Education 12: 27-41. 
29. Paolillo, J.G.P. and Estes, R.W. 1982. An empirical analysis of career choice factors among accountants, attorneys, engineers, and physicians. The Accounting Review 57(4): 785-793.

30. Perry, R.S. 1959. An approach to elementary accounting for non-business students. The Accounting Review 34: 472-476

31. Prosser, M. and Trigwell, K. 1997. Using Phenomenography in the Design of Programs for Teachers in Higher Education. Higher Education Research and Development 16(1): 41-54.

32. Ravenscroft, S.P., F.A. Buckless, G.B. McCombs and G.J. Zuckerman. 1995. Issues in Accounting Education 10: 97-109.

33. Saudagaran, S.M. 1996. The first course in accounting: an innovative approach. Issues in Accounting Education 11: 83-94.

34. Sharma, D.S. 1997. Accounting students' learning conceptions, approaches to learning, and the influence of teaching context on approaches to learning. Accounting Education: an international journal 6(2): 125-46.

35. Shotwell, T. A. 1999. Comparative analysis of business and non-business students' performances in financial accounting: passing rates, interest and motivation in accounting, and attitudes toward reading and math. College Student Journal 33: 181-195.

36. Springer, C.W. and Borthick, A.F. 2004. Business simulation to stage critical thinking in introductory accounting: rationale, design, and implementation. Issues in Accounting Education 19(3): 277-203.

37. Stewart, J.P. and Dougherty, T.W. 1993. Using case studies in teaching accounting: a quasi-experimental study. Accounting Education 2 (1): 1-10.

38. Tan, L.M. and Laswad, F. 2005. Students' beliefs, attitudes and intentions to major in accounting, Accounting Education: an international journal 15(2): 167-187.

39. Toney-McLin, P. 2002. M\&M: a new paradigm for teaching beginning accounting courses. Allied Academies International Conference Proceedings of the Academy of Accounting and Financial Studies, Nashville 7: 95.

40. Zukowsky, W.H. 1961. Essential subject matter for a one-year basic accounting course offered to nonaccounting majors. The Accounting Review 36: 481-487. 